\title{
THE FAILURE OF REMEDIAL JUSTICE
}

"The administration of criminal law in this country is a clisgrace to civilization $* * *$. On the civil side of the courts there is undue delay, and this always works for the benefit of the man with the longest purse."-Presidenr TAFT, Çhicago Speech, Igog.

The writer of this article is not a radical, in fact, he believes himself to be strongly disposed towards conservatism, yet, upon due reflection, he is deeply convinced that, considering the object and purpose of law in its relation to the State, to society, and to the individual, our American system is, upon its remeclial or adjective side, largely a failure.

The Roman jurists emphasized as a fundamental precept the importance of "rendering unto every man his due." Magna Charta, the hallowed bed-rock of English constitutional liberties, reads: "Nulli differemus, nulli vendemus, neque negabimus justitiam;"- "justice to no man will we delay, to no man will we sell, to no man will we deny." Scientific jurisprudence, both Roman and English, is thus historically founded upon the principles of prompt and just, and effective remedies.

The term "remedy" has been interpreted by the courts in a broad and practical sense. The Supreme Court of the United States has said, quoting Blackstone: "The remedy for every species of wrong is the being put in possession of that right whereof the party injured is deprived." 1 It is "the means employed to enforce a right or to redress an injury." 2 Remedies should be effective, because, as said by the Connecticut Supreme Court of Errors: "Every action is brought in order to obtain some particular result which is termed the remedy." 3 Again by the Supreme Court of Pennsylvania it is declared: "A remedy is that which is used to enforce a right or the performance of a dity, and unless it reaches the end intencled, and actually compels performance of the duty, it is not adequate." " Jeremy Bentham, the profound juristic philosopher, said, with clear appreciation of remedial values: "Remedy. in all its shapes.

1 Colnen v. Virginia, 6 Wheat., 407.

2 Warren v. Ry. Co., I8 Minn., $3 \& 4$, quoting Bouvier L. Dict.

3 Wildman v. Wildman, 70 Conn., 707.

${ }_{4}$ Porter Tp. v. Jersey Shore, 82 Pa. St., 278. 
is an instrument having for its use the exclusion of wrong in all its several shapes. Of remedy in every shape, the application made is attended with and productive of burden. The application of remedy, instead of excluding wrong, is productive of wrong, if, and in so far as, it is productive of burden outweighing the benefit." 5

However much one may admire and be devoted to the legal profession, however much he may honor and esteem its judiciary and its long line of able and distinguished men, nevertheless, he who is worthy of the name of "lawyer," in its ancient and ennobling sense, desires to be fair-minded and just, patriotic and serviceable to the public welfare.

We may possibly disregard, with warranted justification, tirades from irresponsible sources, denunciations from unpractical "reformers," extravagant assertions from theoretical sociologists, and savage criticisms from self-seeking demagogues; we may, even with weariness, pass over many of the ill-informed articles upon the "law's delay" in the press, the magazines and the popular periodicals, but we cannot, in wisdom, close our ears to the intelligent complaints and strictures of many of the best and ablest men in our profession, of the deepest students of our laws, and of many of our greatest and wisest jurists. When the President of our country, himself a profound lawyer and distinguished judge, says, as he did last September in his Chicago speech: "The administration of criminal law in this country is a disgrace to our civilization;" and also said: "On the civil side of the courts there is undue delay, and this always works for the benefit of the man with the longest purse," there is need of no motion to make the complaint more definite and certain, and, I may add, more authoritative.

Looking the facts squarely in the face, is it true that the law, whatever may be its substantive excellence, is, nevertheless, as applied, failing to accomplish its great purpose? Does it reasonably meet the practical needs of society? Is its administration, either in civil or criminal cases, such as a majority of good and intelligent men can approve? Is there a widespread respect among the masses for "law?" Is criminal procedure effective and the guilty punished? Is there a reasonable method of redress in civil suits? Is there one law for the rich and another for

s Pannom. Frag. 
the poor? Are just grievances and wrongs rectified without undue expense? Are remedies prompt, effective, adequate? Are abuses prevalent, technicalities absurd, costs excessive, rights delayed? Upon the righteous meeting of these problems the value of jurisprudence as a practical science depends. If law does not to a reasonable extent fulfill the mission implied in these questions, then in its administrative functions, at least, it is. for our day and generation, a failure.

Let us frankly consider some of the facts upon which both popular and professional criticism rest. If it be said that much that follows is not new, a stronger case is made than if it were. That abuses exist may not be blameworthy, since being discovered they may be eradicated. That, however, abuses exist and have long existed, and that we know they have long existed, leaves us in a less creditable position.

In the first place, I believe it is true that there is no other civilized nation in the world where the criminal law is as ineffective as in the United States, and where for the administration of the penal laws there is so little respect. The starting point of this disrespect is in the abusive treatment of arrested persons. Recently I was present, professionally, in the police court of one of our larger American cities. It was the usual Monday morning "round up." Several of the prisoners had been brutally beaten by the arresting officers. It was the same old story, "resisting arrest" on the policeman's part, flat denial on the prisoner's. In one instance, however, I happened to know that the officer lied. What I desire to get at is this. Being somewhat familiar with this country, and having witnessed arrests in such cities as New York, Chicago, St. Louis and San Francisco, and comparing the treatment accorded to the rougher class of petty wrong-doers in America with the methods of the police in London (White Chapel District), Paris, Berlin, and even Constantinople (during the revolution of I908), I believe there is no cloubt that the American policeman leads the world in his unnecessary and brutal use of the club. I except, of course, from this statement thousands of worthy, brave, and efficient police-officers who faithfully and honorably do their duty, and who use force only when fully justified. In the abuse, however, of police authority, the facts are not in our favor. Granting that all this has more to do with the political abuses of our day than with the mal-administration of our crininal laws, it is, nevertheless, a link in the chain. 
Brushing aside these minor matters, what about the treatment of prisoners arrested for felonies, from whom the police desire to obtain evidence? The mere arrest may be quietly made, but then comes, in many cases, that American iniquity known as "the sweat box," "the third degree." The interrogation of accused persons by the police in order to discover, if possible, the evidences of crime. may be. often, justifiable, although, of course, there is no warrant even for this examination in the English common law, but the means, often employed in order to extort confessions, are an outrage upon civilization. They reflect the worst barbarities of the middle ages, and, outside of Russia, are, I believe, the most blameworthy in America of all Christian lands. A Chinaman is arrested for a heinous crime. He is placed in a cell : continually questioned by a relay of detectives and other officials; forcefully kept without-sleep for two or three days, in the expectation that the mental torture and the physical exhaustion will become so acute that he will be glad to "confess" in order to obtain relief. A woman is arrested for murder; at midnight the corpse of the victim is brought to her cell that the dramatic horror of the scene may compel her to "confess." Another prisoner is denied food; another brutally beaten, "slugged" is the worl. until he is forced to speak. Other atrocities are practiced, such as highly salting the food, and denying water to the victims ; placing them in solitary confinement; or in bitterly cold cells. when the weather aids; or in frightfully super-heated rooms at other times. Red pepper has been blown into their cells, and other indignities, too numerous to mention, perpetrated in order that a "confession" may be tortured from a helpless wretch.

Such is a hint of the "third degree" in Christian America in the twentieth century. Admitting, again, that such practices are brutal abuses of authority, criminal, in some instances, in themselves, nevertheless, the shame is that they are clone in the name of the law, and used, in most cases, against humble and friendless inclividuals who regard their jailors as the representatives of the law.

Let us, however, turn to the law itself. It is provided by the Federal Constitution that "no person shall be held to answer for a capital or other infamous crime unless on a presentment or indictment of a grand jury." Although this provision applies only to Federal courts, nevertheless similar constitutional provisions exist in most of the individual States. The grand jury is of 
ancient and honorable. history. It has existed in England for eight hundred years. The King's judges as early as the twelfth century went into the various counties to hold court, and they made inquiry of good and true men of the vicinity concerning crimes committed in the neighborhood. These good and true men, as protectors of society and as clefenders of law, thereupon did accuse, upon their oaths, all malefactors and criminals known to them. In its origin, in its early need, and in its long continued effectiveness, the grand jury was as a system, sensible, protective, just. To-day, however, it is a piece of archaic, legal machinery, a mill-stone upon the neck of justice.

The grand jury must consist of qualified members, must be duly drawn and summoned, and must proceed in accordance with law. If, for example, an ineligible person sits upon the jury, or if an unathorized person asks questions in the grand jury room, the proceedings are vitiated, the indictment invalid. Hence, a murderer escapes in a southern city because a member of the grand jury, as was afterwards learned, couldn't read; and a bank wrecker in a northern city goes free because an accountant, not employed by the prosecuting attorney, was present in the grand jury room and interrogated certain witnesses. These instances are, however, only illustrations of hundreds. The possibilities of irregularities in the grand jury proceedings are so great, the questions that can be raised so multiple, that delays of months or of over a year in the trial of a cause may result. and often have resulted, from this source alone.

It is in the law relating to indictments, however, that one of the chief culture-mediums of the mal-administration of criminal law is found. This written accusation, prepared and drawn by the public prosecutor, receives the formal approval of the grand jury, the jurors, as individuals, being, of course, absolutely ignorant of the requisites of indictments. In other words, whether a criminal prosecution is instituted by the finding of a grand jury, or, as in some States, by direct information of the prosecuting attorney, the grand jury being dispensed with, the validity of the instrument of accusation, as the law, generally speaking, now stands, depends upon the integrity, or the learning, or the good fortune of the draughtsman. Nearly a hundred years ago. Jeremy Bentham, attacking with profound insight and with trenchant pen the like evils of his own day, said: "The power of granting effectual pardon to all criminals-murderers not 
excepted-belongs incontestably to every person by whom the function of penning the instrument of accusation is performed." It is a reproach and a shame to the administration of criminal law to-day that the same charge is still true. A corruptible prosecuting attorney has it in his power to draw an indictment which although apparently invulnerable will, nevertheless, be set aside by the courts. Granting that most prosecuting officers are honest, even granting that they are learned, yet the possibilities of pitfalls are so numerous that only good fortune may save them from adverse and humiliating decisions. A few illustrations from hundreds, all of them actual American decisions, and nearly all of them good law even now in their respective jurisdictions, must suffice:

(a) On the ground that the spelling of the indicated essential word rendered the indictment meaninglcss, indictments are held fatally defective because the word "malice" is written "maice;" because the word "father" is written "farther;" because the word "breast" is written "brest," because the word "larceny" is written "larcey;" because the word "dwelling" (in an indictment for burglary) is written "dwell." The doctrine of idem sonans did not apply in any of these instances, and it may, at this juncture, be pertinent to inquire of the reformed (?) spelling enthusiasts, whether there is not a possibility that some of their recommendations may, indirectly, at some time, add to the present increasing immunity for crime.

(b) On the ground that no word can be omitted which is an integral part of the offense, indictments are quashed because the worl "to" is omitted from the phrase. "intent to kill and nurder ;" because "of" is omitted in the expression "from the possession of."

(c) On the ground that one must not be charged with an offense in language that is disjunctive or alternative, a criminal escapes because the indictment charges the accused with the illegal sale "of spiritous or intoxicating liquor." Likewise, because bacl for repugnancy, in that the accused was named as "Douglas Jones, alias Dug Jones, whose true Christian name is to the grand jurors unknown."

These illustrations should be sufficient to establish the "certainty" in which the bribe-taking or friendly prosecutor may prepare his pleadings for the protcction of the accused, and, on the other hand, to show the perils into which cven the most careful 
and most zealous public attorney may fall. I have, however, before me two or three other decisions which I wish to present.

(I) A is indicted for defrauding the "First National Bank of G." Indictment held fatally defective because it does not state whether such bank is an individual, a partnership, or a corporation. An ordinary person might presume, of course, that a "National" bank was a corporation, but it is a sufficient answer to "an ordinary person" that although he is presumed to know the law, yet he doesn't.

(2) The Supreme Court of a grand old State sets aside an indictment because the "—_ Railroad Corporation" (its legal name) is designated as the "_ Railroad Company."

(3) I have just looked at the advance sheets of a late Illinois decision. Two men were convicted, in Chicago, of the forgery of a note. There seems to have been no question as to their guilt. The Supreme Court, however, has just set aside the judgment and discharged the defendants because the indictment in describing the note read that it was "in substance as follows." (The italics are mine.) Now it is the rule that forged instruments, unless destroyed or otherwise non-accessible, must be set out according to their "tenor," that is, set out in an exact copy. The court holds, however, that the words "in substance" does not purport an exact copy, and, therefore, the indictment is fatally bad. Despite the glaring fact that the instrument was literally copied word for word into the indictment, and despite the admission of the court that, if the words "in substance" had not been inserted, the words "as follows" would have been satisfactory as showing "tenor." the criminals escape, the county pays the expenses of a fruitless prosecution, and injustice winks one of his alway's opened eyes at the blinded face of the helpless goddess. "But this is a perversion of the law," one may contend. Not so, it being important to unclerstand that, on the contrary, it is good law. "Well, it ought not to be good law," the objector may continue. In that I agree with him.

After the indictment the trial, or rather after the indictment the deluge, because thus far we have been gathering mere shells or pebbles while the great ocean of technicalities, abuses, and delays lies before us. There are many dilatory steps, in our American practice, that keen and cunning advocates may take between the indictment and the trial. There are possibilities of motions, pleas to the juriscliction, pleas in abatement, demurrer, absence of 
important witnesses, other engagements of counsel, in fact, possibilities enough to postpone and delay the trial for months and even years. The courts are not, as a rule, to blame, since under the present state of the law, judges are given too little power to hasten the day of trial. Our system, as President Taft says: "Is a game in which the advantage is with the criminal and if he wins, he seems to have the sympathy of a sporting public." On the other hand, while the delay is largely brought about by the fertility of expedient on the part of counsel for the defense, is he not justified in taking advantage of every technicality possible in his client's favor? As long as defending counsel acts zoithin the law, it is his duty, I believe, to safeguard the interests of the accused in every honorable way. Granting that pettifoggers, shysters, and "legal-fences" may be often guilty of many dishonorable practices in the defense of criminals, yet many of the ablest and most respected members of the bar are retained in criminal cases, men whose integrity is unquestioned, whose honor is unassailable. The fault, therefore, lies not with the courts, or with the defendant's lawyers, but with the system itself.

I must, however, hasten. The limits of an article such as this do not afford opportunity to point out with satisfactory detail or specialization many of the existing evils. It is necessary, therefore, to speak very briefly, to merely state the case without presenting the evidence. As regards the trial of criminal causes, some of the fully justified complaints are as follows:

Our trials are too long-drawn-out, disgracefully so. In notorious cases exciting widespread public comment, a week or two weeks is often consumed in selecting a jury. The time, furthermore, taken up in examining witnesses, is one of the most prolific causes of just criticism, coupled, as it is, with the possibility of reversible error, upon review, in the court's rejecting or admitting evidence, although often of a trifling character. Our system is faulty, further, in not giving the judges greater authority to keep the trial moving, to exclude much of the testimony that now is admitted as relevant, and to keep the witnesses down to the salient points of the case, as is done in the English courts Frivolous objections on the part of attorneys as to matters of evidence should be severely suppressed, and members of the bar should be made to understand that the tribunals of justice represent one great department of the State's business, and that the court room is not an arena for dramatic self-exploitation. In con- 
nection with this statement, the writer recalls that, some years ago, he heard an ambitious "criminal lawyer" loudly lamenting the fact that the death penalty had been abolished in his State, since no longer would he have the opportunity "to plead for a man's life, a very effective weapon in a capital case," said he, "to use with the jury."

The most abused doctrine in criminal law is, however, the defense of insanity. So much has been said and written upon this subject, that it is superfluous to add anything here, but there is no greater reproach upon the American system of criminal procedure than this. As in almost everything else criticisable in our laws, the fundamental principle, the substantive law is sound, is scientific, but in its application, in so far as it relates to the adjective law, it is disgraceful. Nothing better illustrates and better justifies the popular clamor of "one law for the rich, another for the poor" than the miscarriages of justice that are frequently witnessed in this country from this cause. "Expert testimony" in connection with this defense has become a by-word, a mockery, a mere prostitution of great talents for shameless hire. Numerous specialists are engaged, large sums of money expended, and a criminal trial prolonged for days, and even weeks, upon an issue of whether or not the accused was insane at the time of the commission of the act, when, were it not for the exigences of the case, no one would have even suspected the mental irresponsibility of the defendant. Then, in addition, what is more farcical, more absurdly idiotic, than the practice of submitting to the "expert" a long, hypothetical question, often thousands upon thousands of words long, containing a synopsis of all the evidence, requiring, sometimes, nearly a whole day to read it, and, then, answered by a mere "yes" or "no," when everybody understands just how it is to be answered by the particular witness?

To such an extreme has society been wronged and justice been mocked by this plea, that, very recently, a special committee of the bar association of a great State (a commonwealth that has peculiarly suffered from this travesty upon justice) has gone so far as to recommend the abolishment of insanity as a defense in criminal cases. While such a step would be wrong, because legally unscientific, nevertheless, much needs to be done to correct the present procedure. 
There are two other matters I desire to touch briefly upon in connection with the trial, namely, the summing up by the counsel, and the charge by the court to the jury. The time allowed counsel to sum up the case, the latitude given for irrelevant outbursts of eloquence and parabolas of oratory, are further causes of demoralization. In a recent sensational case in Memphis, one attorney spoke for six hours, an admiring newspaper saying of his address:

"His audience wept without restraint under the spell of his pathos, and flamed with red-hot wrath -"

In a notorious case in New York, a whole day was not sufficient for the closing address of counsel for the defense, the burden of his appeal being an entreaty to the jury to disregard the law of the case, and to show by their acquittal of the prisoner that they agreed with the speaker in the existence of an American code that was higher than the law of the land. It is indefensible by any correct principles of law to permit counsel to depart in their arguments from the law and the evidence of the case, and a lawyer who seeks by impassioned appeal to persuade a jury to disregard the law of his country, urging them, in substance, to violate their oaths which were solemnly given to decide the case "according to the law and the evidence," should be publicly censured by the court, and he should, furthermore, be disbarred.

As to the charge by the court, into what a maze and tangle our modern procedure has grown! No longer, in most jurisdictions, is the judge permitted to sum up the evidence and to enlighten the jury thereon, which was formerly the chief duty of the court, and which fact lay at the very foundation of the theory of trial by jury, but he is compelled to hastily decide as to the law upon a voluminous mass of requests to charge, involving many intricate questions, cunningly devised by keen and adroit advocates, in any one of which, either to refuse to charge, or to charge as requested, he may fall into reversible error. He must, thus, decide, off-hand, complicated questions of law, which a reviewing court has the opportunity to consider at leisure, with the help of briefs, arguments of counsel, and consulting associates. The system is wrong, injurious, unscientific, absurd.

Compared with the length of trials in this country, how different it is in England, the home of our common law!

I am not one who is fond of extolling English institutions a; superior to our own, yet, having attended a number of trials of 
civil cases at the Law Courts in London, and having observed the procedure in the Central Criminal Court at the Old Bailey, candor compels me to say that in the prompt dispatch of business the English courts are able to teach us much. Only last summer, to cite an illustrative instance, the trial of Lal Dhingra, the young East India student who murdered Sir Curzon Wyllie, lasted less than two hours. It is true he had no counsel, no provision existing in the English law for the appointing of counsel by the court (which, of course, is unjust), but that fact did not probably hasten matters. The witnesses were called in rapid succession; the questions were brief and leading (permissible in the English direct examination), the presiding judge (none other than the Lord Chief Justice) permitted nothing to be said or done that did not bear directly upon the issue. All was over, the prisoner convicted and sentenced to death, in less than a hundred minutes, and no reasonable man could say that the accused did not have a fair trial in accordance with English law. Of course, this was a clear case, but is it exaggeration to say that, in this country, a similar case might have been prolonged for days if not for weeks?

Space does not allow me to dwell upon what is the greatest delay of all in our procedure, namely, our system of appeals. If the possible delays before the trial are a source of grave injustice to society, what is to be said of this greater evil, the comparative ease with which a convicted criminal, providing he is well supplied with money, may even for two or three years postpone the end? In the case of a poor man, the result may be different. One illustration must suffice. Not long ago, in the city of Chicago, a murder trial resulted in conviction, and the defendant was sentenced to death. He naturally desired to appeal, but he was destitute of funds. The cost of preparing a transcript of the record was estimated at $\$ 700$, but this he could not raise. The final day for the filing of the transcript in order to perfect his appeal and thus to obtain a stay, was almost at hand, and had not some sympathetic person, a stranger to the accused, it is said, contributed the necessary costs as a gift, the year or more of life which was thus secured to the prisoner by the stay would not have been possible. Granting that the conviction was just, that the prisoner was a notorious criminal, nevertheless, it is a shame to American jurisprudence that, under the administration of its criminal law, the lack of a few hundred dollars may send, to-clay, 
one convict to the gallows, while the possession of it may stay the execution of the sentence of another criminal for a year or more, with the possibility of a final reversal tor error in the voluminous record.

A very brief epitome of the abuses in civil proceedings is all that my almost consumed space permits. The average man dreads to carry his just but small claim into court. Even though he may obtain judgment, and costs may be thrown upon the defendant, yet the unreasonable delay that may follow by appellate proceedings, and the expense of attorney's fees, combine to deny him justice. Even if his claim is for a substantial amount, it is possible, among the many technical reasons for postponement, that several years may elapse between entering the case for trial and the actual hearing. In no demagogic spirit, (for the corporations have their just rights as well as the individual, and hundreds of dishonest personal injury claims, for example, are filed against railway corporations every year)-in no demagogic spirit, but in all fairness, I ask, what show for equal justice has the poor man in a civil suit against a wealthy corporation or against any rich defendant?

Frivolous appeals are often taken just to wear complainants out. Then, too, with all our boasted reformed (?) procedure, pleadings are too prolix, too many cases are appealed on mere questions of pleading arising on clemurrers to complaints or answers, involving inevitable costs, and cases without end go up upon such questions as whether or not the trial court erred in allowing or refusing amendments to pleadings. Upon appeal, additional long delays must intervene. Reviewing courts are congested with business, the record is needlessly cumbersome, and the expense too great. In many jurisdictions reversals may follow upon technicalities that do not affect the merits of the case, and the wearisome grind may start all ovor again.

The explanation of the existing abuses in remedial jurisprudence is, broadly speaking, three-fold-namely, adherence to obsolete rules; selfishness; indifference. Our adjective law grew up, historically, in the English courts, and the rules of procedure were, originally, established in reason and in justice. Take the procedure in criminal cases, for example. The rational origin of the grand jury has already been referred to, and the technical rules regarding indictments were mainly developed in a spirit of merciful justice. The former penal laws of England were writ- 
ten in deeper blood than were the laws of Draco, and many of the niceties as to pleadings in indictments were exacted for the protection of the accused. In truth, the multiple technicalities of criminal procedure, coupled with the rule of strict construction, is, historically speaking, a monument to the sense of justice of the English common law judges in defense of the rights of the defendant, "when barbarous law," as Prof. Maitland says, "was tempered by luck." The reason, however, of many of the old rules has been effaced by a better age, and to-day, the application of many of them has, by a reversal of conditions, become an instrument of injustice to society. The criminal is now unduly protected while the sense of justice of the people at large is violated. The reasons for the old rules failing, the old rules should likewise fail. No indictment or information should be quashed for any clerical omission that ordinary common sense readily perceives to be such an omission, or for any defect, imperfection, surplusage, or repugnancy, which is purely technical, providing sufficient matter is alleged to distinctly charge the offense and to indicate the person, and also provided that the substantial rights of the accused upon the real merits of the case are not prejudiced. The statutes of some of our American States already provide for such reforms, while it is to the credit of the broader spirit of jurisprudence of some of our judges of other States that, even without the enabling authority of statutes, they have sustained indictments that upon frivolous objections have been quashed in other jurisdictions.

Almost all of the other many absurdities in our administration of law may be explained, historically, in the same way; for, as Montesquieu says: "Il faut eclairerl' histoirc par les lois, et les lois parl' histoirc." "At the beginning, rules, now ridiculous. were sensible and just, but they have long outlived their day." Take for instance our much heralded "trial by jury." We still apply to the system theories that were excellent four hundred years ago, but which in our times are utterly absurd. Moreover, very few who seem to make such a fetish of "the common law" stop to reflect that our notion of a jury, the triers of fact upon the testimony of other persons, was practically unknown in England when this country was first settled. It is true that the heir of intolerable conditions may not be responsible for descent cast, but he may certainly improve the inheritance during his tenancy thereof. 
The two chicf causes of the retention of the evils complained of are selfishness and indifference. Selfishness, because the law is regarded by many lawyers as a trade, a mere matter of business, a livelihood. The thought of self-interest and of client's welfare is larger than the thought of the state, the nation, the people. The lawyer should be a social philosopher, a real student and advocate of social science, not leaving these great problems to others who, often, in their ignorance of law and of legal institutions, harmfully meddle with so-called legal reforms. It is not a question of business, not a matter of income, but whether the law as a great science, like the science of medicine, and the science of theology, is fulfilling its destiny, is meeting the needs of society. If it is better for the purpose of furnishing cheap and prompt remedies for certain classes of the people, that tribunals should be instituted for the settlement of small claims, from which tribunals all lawyers as representatives of litigants are excluded, then lawyers should favor such courts. The Traders and Merchants Courts in Berlin (Das Gezerbegericht zu Berlin, organized in I893, and Das Kaufmannsgericht zu Berlin. organized in 1905) are interesting examples of such tribunals By statute no lawyer is allowed to appear for a party in these couris. The amounts involved are small, but justice seems to be dispensed with much success. Disputes are quickly settled and with almost no expense.

In contradistinction with this view, I recently heard an old lawyer protest against any simplifying of pleadings and procedure, "because such things enabled the young and inexperienced lawyer to get his case into court just as well as the older and more experienced man." It reminds one of Lord Hobart who in justification of technicalities is reported as saying: "These things exist that the law may be an art."

Where, however, some lawyers are selfisl, many more are indifferent. Able and conscientious members of our profession, although recognizing many of the existing evils, nevertheless say that abuses are deeply seated, that they have long existed, that in one form or another they have been the targets for criticism for many generations, that there is no panacea for the law's delay, that much of it is inevitable, that the real explanation of it all is to be found in the people themselves, in litigants, and that there will have to be a general reformation of selfish 
human nature before "the impractical dreams of theorists" can be realized.

Such statements contain something of truth but, nevertheless, more of error. If the present evils in our legal system are to be remedied, the work must be done by the lawyers, because no other class of men can do it. Only men thoroughly trained in the law, its history, its practice, its needs, are able to intelligently improve conditions. I yield to no one in my profound admiration for the legal profession. In all the ages the ablest of men have been enrolled in its ranks. From the days of the Roman praetor to the present it has been the jurist, the philosopher in governmental and legal science, that has done most for the State, and it must always be so. The great cause for regret, however, is that so few lawyers seem to realize the debt they owe to their profession. Are not the remarks of Mr. Bryce, the present distinguished Ambassador from England, equally applicable to our own country? In his valedictory lecture at Oxford, he said with deep regret: "There are few countries in which so small a proportion of the men engaged in professional work show an active interest in legal reforms." Nevertheless, that same country, whose obsolete legal principles we still so largely and so blindly follow, has far outstripped our own in many phases of legal advancement.

Not only ought this work to be done by the lawyers, but it will, in my opinion, be done by the lawyers, and there is already encouragement in many directions. In some American States, the quashing of indictments, for example, for trivial causes, such as have been superficially illustrated in this article, is no longer possible, owing to statutory provisions. Bar associations are awaking to the necessity of dealing with these problems, and many of the leaders of our profession are using their great influence in the right direction. At Chicago, last June, the organization of "The American Institute of Criminal Law and Criminology," having among its objects the simplifying of pleading in criminal cases and the elimination of unnecessary technicalities, is a further illustration of the interest now being shown by lawyers in these questions. The creation of juvenile courts for delinquent children, another credit to the profession, is one of the greatest steps taken in recent years towards social betterment.

If Burke was right, and I believe he was, when he said: "There are two and only two foundations of law-equity and 
utility," and if one may be permitted to paraphrase his statement. the propositions I have desired to maintain are these: Law as a practical science must necessarily, by evolution, be adapted to the changing needs and conditions of changing society. The best system of remedial justice is that which best promotes the peace, the prosperity, the welfare of the whole people, and which equally protects the interests and liberties of the individual citizen without, however, doing injustice to the State; and by which even the humblest man can obtain his just rights without unreasonable cost and without unreasonable delay.

\section{University of Kansas.}

Willian L. Burdick. 